\title{
Contribution of Restorative Justice Practice in Baduy's Culture Criminal Justice System Reform
}

\author{
Umi Rozah ${ }^{1}$ \\ \{ Email: umi_rozah@yahoo.com ${ }^{1}$ \} \\ Diponegoro University, Jl.Prof. H. Soedarto, S.H. Tembalang, Tembalang, Kota Semarang, Jawa \\ Tengah, 50275, Indonesia ${ }^{1}$
}

\begin{abstract}
Criminal justice system emphasizes on an offender-oriented paradigm, such as how to impose an appropriate and a fair punishment to the offender. On the other hand, the victim has no right in the criminal justice system, with a unique role as the key witness. This article based on research which had performed in Baduy, Banten Tangerang Indonesia. This research rests on the socio-legal research approach by using hermeneutics philosophy. The research outcomes are as follows: The values contented on restorative justice practice in Baduy's culture can be identified within criminal justice process, such as 1) Victim and his/her family have a position similar with offender in the adjudication process; 2) All process in the adjudication aims to restore all damages and injuries, to restore and clean up of the offender's inner, and to restore peace, cosmos, and social re-cohesion; 3.All process will end with restitution, forgiveness, and punishment, if the conference could proof the offense and blameworthiness of the offender. Criminal Justice System applied in Indonesia today is based on the old concept, which only focuses on the offender and less to the victim. Restorative justice practices in Baduy culture can be applied in the adjudication. There are two types of adjudications in criminal cases: family conference and the Customary Criminal Court. All types of adjudication have to involve the victim and his/her family. This restorative justice concept can be applied in criminal justice system reform to achieve substantive justice for all parties.
\end{abstract}

\section{Introduction}

The criminal justice system is a system in criminal law which enforces substantive criminal law by punishing the threatened in criminal law code. Here, a criminal justice system which works throughout criminal justice process rests on balancing interest between the State's interest that represents the victim's interest, whereas the burden of the victim to avenge the offender rests on the prosecutor function with the offender's interest. However, the offender is considered as a powerless citizen before the criminal justice system whose rights and interests must be protected by the State, which brings in an offender-oriented paradigm in the criminal justice system. The process in criminal justice only rests on how to impose an appropriate and fair punishment to the offender (offender-oriented or daderstrafrecht paradigm).

On the other hand, there is a victim as a party who had the most suffering because of the offender's conduct. The victim suffered some harms or injuries, such as life, body, properties, dignity, etc. As a party in the offense, the victim has significant interests in the criminal justice system. However, the victim's position is not equal to the offender in the criminal justice process. The victim must be satisfied with the punishment which is imposed by the judge, even if the punishment is less or more than indictment in prosecution 
and unproportionate with the damages done by the offender. If the judge imposes the light punishment that is not equal with the injuries or harms suffered, the victim must accept it. Because of the offender-oriented paradigm in criminal law enforcement, victim has no chance to express his/her injuries, to claim that the offense has caused effect and affected his/her and family life, to submit a demand upon her/his restitution, restore of his/her injuries or harms, or to propose any punishment which is proportionate with his/ her injuries.

The position of victim in the criminal justice system is only as the key witness who has to testify about how the offense had been done by the offender to him/her, what the victim did when the offender made him suffer, such as taking his/her properties, injuring his/her body, or taking the life of his/her member of family. As the key witness, the victim is needed to extract his/her testimony about all things associated with the offense, and after testimonies had been given either in the investigation, prosecution, or examination in the court by the judges, all the interests of the victim in the criminal justice process are over as well. Furthermore, the criminal justice process works as a fight between the offender with the prosecutor as representative of victim interests. Here, there is no balancing position between the victim and the offender, even if the judge imposes the light punishment, which is disproportionate with injuries or harms.

Indonesia as a country that consists of cultures and tribals with a diversity of customs, languages, and majority religions, has parallel values that rest on harmony and peace in the social relationship between society member and the cosmos they live in. These genuine values of harmony and peace are applied in settlement of prohibited conducts or offenses that occurred in their cultural life, which emphasize on equilibrium interest of the victim, offender and society with cosmos where they live in.

How to answer challenges in the criminal justice system that give the victim a position before the criminal justice process as a party who had significant interests for the performance of the criminal justice process same with the offender? Here, there is a need to reform the criminal justice system that emphasizes on the victim's interests to restore harms or injuries and to achieve fairness between the offender, victim, and society.

This article based on research which was performed by socio-legal research approach and restorative justice approach. The research was held in Baduy, a region in Indonesia which has a unique culture in restorative justice practice, which is considered as a contribution to criminal justice reform. The values of restorative justice underlie Baduy's culture in their criminal justice practice that places a balanced position between the offender and victim, function of a combination of punishment, restitution, and forgiveness in the adjudication of criminal conducts throughout Customary Criminal Court. Therefore, the research problems are as follows:

1. What values were contented on restorative justice practice in Baduy's culture?

2. How to reform the criminal justice system based on restorative justice practice in Baduy's culture?

\section{Methodology}

This article based on research which had been performed in Baduy's Culture, located on Region of Banten - Tangerang Indonesia. This research emphasizes on socio-legal research approach as an alternative approach which examines doctrinal study to the law that represents the relation between the contexts where the law lies (an interface with the context within which law exists). Here, hermeneutics philosophy had been used in this 
sociolegal research as well to inquiry and to assess about how the restorative justice was performed in practice to settle criminal conducts which threatened any punishment in their society based on the source of the living law values that applied in Baduy's culture. This research also used constructivism paradigm or interpretive paradigm, to understand the relative truth of reality, that applied by the specific context which is relevant to social actors. This constructivism research paradigm had been used to search perceptions of research subjects on custom in the adjudication of criminal matters that emphasizes on victim's interests based on people's experiences on social life, religion, culture, and values system of the subject.

\section{Literature Review}

Crime is the primary norm; punishment is the sanction. Crime without punishment, or at least the threat of punishment, maybe impractical, but it is not illogical[1]. "The reason for punishment listed above fall into two groups: those which concern with preventing future crimes, and those which concern with punishing what was already committed (or past crimes)[1]. The essence of punishment for moral delinquency lies in the criminal conviction itself. It is an expression of the community's hatred, fear, or contempt for the convict with alone characteristic physical hardship as punishment[2]. As we have known, the criminal justice system has retribution framework to punish the offender as the one should be imposed punishment as the shape of retaliation of the victim and responsibility of his/her offense. This system only emphasizes on the offender interest as a weak party before the criminal justice process. Retributive frameworks have predominated within the legal system. Retributive justice focuses on punishing offenders, but it does not always consider victim needs. Traditional criminal justice models allow minimal interaction between victims and offenders[3].

At the same time, the system alienates the victim, making him or her feel like an outsider to both the offense and the system processes. Today, however, the victim has evolved into nothing more than a critical witness[3]. Victims suffer at the hands of their offenders. Some people may be injured physically; others may lose property during the attack. All will be gripped to some extent, with fear and mental anguish. This aspect of their victimization experience will affect their quality of life and probably will not subside for quite a while. Victims who turn to the criminal justice system for comfort and solace quickly learn that they run the risk of being exploited. The system, through its impersonal and detached mechanisms for sorting through cases, aggravates the victim's condition[3].

In addition to sustaining physical injury and property loss or damage, a sizable proportion of victims reported losing time from work and their regular routines. They also endured emotional anguish and interpersonal complications with family members and friends[3]. In the 1990s, writers sharing or sympathetic to abolitionism or at least drastic reduction of the penal sphere have further developed ideas about procedures which could replace those of present criminal law and about changing the normative orientation of law from retribution to restoration[4].

There has thus been a need for justice procedures and philosophies that focus on victims, as demonstrated in the victim-advocacy movement. A primary aim of the restorative justice movement is to preserve the rights and dignity of both victims and offenders[3]. By the end of the 1980s, the 'negative reform' strategy advocated by Mathiesen seemed inadequate to meet the challenge of the new law and order climate; new theories reductionists which try to address the claims of actual victims and communities of 
potential victims on criminal justice systems. What has emerged as a positive alternative to retributive criminal justice is restorative justice[3].

Restorative justice is a theory of justice that emphasizes repairing the harm caused by criminal behavior. It is best accomplished through cooperative processes that include all stakeholders. This can lead to the transformation of people, relationships, and communities[5]. The overall purpose of restorative justice is not to inflict punishment in proportion to the seriousness of the offense, or to incapacitate offenders so that they pose no further risk to the public, but 'the restoration into safe communities of victims and offenders who have resolved their conflicts'[6].

Restorative justice procedures often provide opportunities for offenders and victims to meet together in carefully supervised settings with trained mediators. (Sometimes such sessions replace regular sentencing, but by no means always.) In victim-offender conferences, offenders have opportunities to hear the victim's perspective, to apologize, to explain their actions, and to offer restitution, all of which can facilitate forgiveness by victims[3].

The main principle of this restorative justice approach is that the task of criminal justice should be the restoration of relationships and balance of advantages and disadvantages that have been fractured by the harmful action (the 'crime,' in the present vocabulary of criminal justice). This basic principle is familiar to many formulations, but a particularly well-reasoned and thorough exposition that is 'redress.' 'Redress' means that the restorative process is started by a 'victim' claiming redress: 'To claim redress is merely to assert that an undesirable event has taken place and that something needs to be done about it [6].

Restorative justice involves the process of returning to their previous condition, all parties involved in or affected by the original misconduct, including victims, offenders, the community, and even possibly the government. Under this punishment philosophy, the offender takes full responsibility for the wrongdoing and initiates restitution to the victim. The victim and offender are brought together to develop a mutually beneficial program that helps the victim in the recovery process and provides the offender with a means of reducing the risks of re-offending[7]. Ideally, offenders will appreciate expressions of forgiveness. Assuming that they acknowledge some responsibility for wrongdoing, perpetrators may feel grateful to receive forgiveness, especially if forgiveness seems undeserved. The resulting feelings of gratitude (or perhaps guilt) at being over benefited may motivate offenders to reciprocate goodwill through improved behavior and reparations[3].

\section{Finding}

\subsection{Restorative Justice Values in Criminal Adat Court Practice of Baduy's Culture}

Baduy call themselves Urang Kanekes is the name of their sacred territory, located in the Kendeng Mountains in south Banten, Java, Indonesia. They live in the Western part of the Indonesian province of Banten, near Rangkas Bitung. Their population is centered in the Kendeng Mountains at an elevation of 300-500 meters above sea level. Their homeland in Banten, West Java is contained in just 50 square kilometers from Jakarta. To ensure the protection of their customs, Baduy society is divided into two groups: the inner Baduy or holy member of the hierarchy, occupying three sacred villages namely Cibeo, Cikeusy, and Cikartawana located in Tanah Larangan or Forbidden Territory. They protect their community from exposure to external influences in order to ensure purity. Various taboos impose seclusion upon them and prohibit the import of any forms of modern technology (except knife blades). The holy members also discourage outsiders from gaining access to 
their community. They always take care of their Adat (or customs) strictly through the ways of traditional life either in the social life or in the adjudication of prohibited conducts throughout the Customary Criminal Court of Baduy.

The prohibited conducts according to Baduy's criminal law are divided into two types of offenses: 1) Severe or severe offenses that involve arcane or inner interests, such as murder, torture, adultery, and rape; and 2) Minor offenses which involve material interests, as like theft, fraud, embezzlement, and other offenses on material interests. This division of types of offenses brings consequences on different adjudication of these offenses. Here, murder and adultery are the most serious offenses, as these offenses involve the arcane or inner interests of the offender, victim, society, and nature impassivity at once. Baduy's culture always takes care of cosmos balance in their life between social and supernatural life, which is believed to protect them from all bad things. They believe in Karma that it will occur as a retaliation of God, not only to the offender but also all people who live in that village as well. Severe offenses like murder and adultery are interpreted as a disturbance to the cosmos and summoned the anger of nature and God, so the Customary Criminal Court must do adjudication by the conference which involves either family of the offender or family of the victim, leader of society, and whole member of the society. It is different from minor offenses like theft, fraud, etc. which only associate with material interests. The adjudication for minor offenses was enough throughout the discussion in a family conference.

There are stages of adjudication based on types of offenses, as follows:

1. The Family Conference

This stage is the adjudication to settle the minor offenses. The conducts of the minor offenses are offenses that did not involve the arcane or inner interests of the offender and victim. The offenses are only outwardly interests and considered as minor offenses that can be adjudicated by the family conference. Here, either family of offender or family of victim meets up to settle the offense together, seek the solution which gives advantages to all parties involved in this case. For this process to involve the leader of Adat, it depends on the willingness of all parties involved in the offense.

The family conference is done in order to seek a settlement that gives advantages for all parties, either offender or victim and society. This conference was begun by the confession from the offender about his/her conducts to the victim and his/her family, and then there is a reconciliation wherein the offender asks for forgiveness to the victim and his/her family. Here, forgiveness was the most crucial thing that depends on the victim and his/her family, but in order to find the solution which gives a win-win solution, usually, the victim and his/her family forgive the offender. Forgiveness is the most important thing to continue this adjudication. After they forgive each other, then it is the victim's turn to ask for reparation of his/her injuries to the offender throughout restitution. The shape of restitution can be reparation of the property which is damaged on the offender's hands to the original shape, replace of the property which is stolen by the offender, or amounts of money which are proportionate to the number of damages.

Furthermore, after an agreement was achieved, the offender or his/her family should perform "ngabokoran." Ngabokoran is a ceremony to restore and to clean up the offender's inner or arcane and to restore the cosmos which is disturbed by the offender's conducts. Here, all type of punishments is meant to restore all damages. Ngabokoran also reflects how serious the offense that offender did and how severe the punishment on offense is, and also how much restoration of damages which the victim asked for.

2. The Customary Criminal Court System 
The Customary Criminal Court System is a system of criminal justice in the Customs Law in Baduy culture. Here, the criminal law enforcers consist of "Puun," "Jaro Tangtu," and "Baresan" in the Inner Baduy, and "Tanggungan or Jaro 12" and "Tangkesan" in the Outer Baduy. The Customary Criminal Court System handles the most serious offenses that involve personal or arcane interests, such as murder, adultery, torture, and rape. The roles of the Customary Criminal Court is examining the case, imposing any punishment, assessing the restitution asked by the victim, and determining the "ngabokoran ceremony."

Meanwhile, the types of punishment in Baduy's culture are as follows: a. Verbal sanction; b. Advice by Puun to the offender and his/her family; c. 40 days Imprisonment; d. Ngabokoran, and e. Exile from the village. All punishments are done in order to clean and to restore the inner or arcane of the offender and society and cosmos, to avoid of retaliation of God and nature, and to achieve peace and social cohesion. All punishments are imposed in order to give balanced interests between the offender, victim, and society proportionally.

Associated with imposing punishments above, the Customary Criminal Court performs adjudication through the following stages:

1. The Customary Criminal Court process is begun by the report from the victim which suffered injuries because of the offender's acts. The report is submitted to Jaro Tangtu in each village where the victim lives. Based on this report from the victim, Jaro Tangtu then collects the facts and data about the case, that informed by the offender, victim, and witness. Jaro Tangtu then calls all parties to meet up, to investigate, and to collect evidence.

2. After enough evidence is collected, Jaro Tangtu brings all evidence and all parties to the Customary Criminal Court, which is lead by Puun as a leader of the village. There are three Puunsin lined with the number of villages in the inner Baduy.

3. The criminal justice process goes on with indictment that submits by Jaro Tangtu as a prosecutor. The victim and his/her family have to attend in this process and have equal standing with the offender. The victim has a voice to be heard on his/her suffering caused by the offender's offenses, his/her awful experiences with the offenses inflicted on them, how the offense had affected to his/her life, and ask for restitution to restore injuries or damages.

4. Then conference assesses the proportionality of restitution asked by the victim with measuring the capability of the offender to fulfill it. All properties of restitution will be submitted in Ngabokoran ceremonial. If an agreement between victim and offender had been achieved, then Puun, Jaro Tangtu, a leader of society and restitution assessor has a discussion to determine how much restitution that must be paid by the offender or his/her family, and date and day of Ngabokoran ceremonial performance.

5. As long as waiting for determining of Ngabokoran ceremonial, the offender must go through a period of his waiting in a detention house (Rutan Adat Baduy) for 40 days. Detention house is a place as like a house that functions to isolate the offender in order to think and regret his wrongdoings and to repent from any prohibited conducts.

6. As the purposes of punishing by Customary Criminal Court, Ngabokoran acts as an ultimate punishment that abolishes the offender's sins and restores cosmos and peace.

\subsection{Criminal Justice System Reform Based on Restorative Justice Practice in Baduy's Culture}

Law is a mirror of society, which functions to maintain social order. The first idea is that law is a reflection - a mirror of society. Every legal system stands in a close relationship to 
the ideas, aims, and purposes of society. Law reflects the intellectual, social, economic, and political climate of its time. The second idea is that law maintains social order by establishing and enforcing the rules of social intercourse and by resolving disputes [8]. Meanwhile, criminal law and the system of punishment as a way in which society expressed its rules and values, the moral boundaries were defined and maintained by the pronouncement of penalties for the crime[6].

As we know before, the criminal justice system only focuses on the offender and less on the victim. It needs a long time to achieve the ending of the criminal justice process to prove the offender's conduct and fault, which is later ended by the release or punishment of the offender. The process is similar for either serious offenses or minor offenses. It is Customary Criminal Law as customary law in criminal justice, which emphasizes on restoration justice purposes. It searches for a win-win solution wherein the offender and the victim get the same advantages, to restore all damages, to restore peace in society and the whole cosmos.

Baduy criminal law regulates the prohibited conduct which threatens offenders by punishment and adjudicated it by the measures which involve victim, offender, and their family. With the restorative justice concept in the practice of adjudication offenses, all types of punishment in Baduy' culture aims to restore and to clean up the body and soul of the offender, society, and cosmos.

Here, the criminal justice process is performed based on types of the offenses; if the offense is only minor, then it can be resolved in family level through family conference which involves the family of the victim and the family of the offender. If the family conference worked well, then a trial in Customary Criminal Court is not needed. Meanwhile, the severe offense is considered a highly dangerous offense. Thus, it could not be resolved in the family conference, and the case should be brought to the Customary Criminal Court. Here, a victim has a right to state how the offense has affected his/her life, and then ask for restitution at once. If the court could prove the offense and the offender's fault, then the judges impose him/her punishment. This process involves punishment, forgiveness, and restitution wherein victim or/and his/her family has a position in the criminal justice process to state victim's interests and has a voice to restitution payment. The criminal justice process aims to restore all damages, clean up the inner of offender and society, and to restore cosmos. All principles of restorative justice applied in Customary Criminal Court practice in Baduy can be applied in Indonesia Criminal Justice System reform.

\section{Conclusion}

The values contented on restorative justice practice in Baduy's culture are as follows: 1. The victim and his/her family have a similar position with the offender in the adjudication process to search for a solution that gives the same advantages; 2 . All process in the adjudication of the criminal case has purposed to restore all damages and injuries, to restore and clean up of the offender's inner, and to restore peace and social cohesion; 3.All process ends with restitution, forgiveness, and punishment if the conference could prove the offense and blameworthiness of the offender.

Criminal Justice System applied in Indonesia today is based on the old concept, as it only focuses on the offender and less to the victim. Victim or his/her family has no role in this system. Restorative justice practices in Baduy culture can be applied in all adjudication of criminal cases. There are two types of adjudications: (1) family conference to adjudicate 
minor offenses that do not involve the personal interests, but only material interests; and (2) the Customary Court to adjudicate serious offenses or severe cases which involved the private interests. All types of adjudication have to involve a victim and his/her family. This restorative justice concept can be applied in criminal justice system reform to achieve substantive justice for all parties.

\section{ACKNOWLEDGMENT}

My gratitude goes to Faculty of Law Diponegoro University for allowing doing the research. I also thank the key informants such as Mr. Sarpin as the leader of the Baduy Luar and Mr. Mursid as the leader of the Baduy Dalam.

\section{References}

[1] K. A. Findley "Reducing Error in the Criminal Justice System," Seton Hall L. Rev, Vol. 48 p. 1265,2017

[2] W. L. Craig "Is Penal Substitution Unjust?," International Journal for Philosophy of Religion 83(3) p. 231-44, 2018. See also R. Canton "Probation and the Philosophy of Punishment," Probation Journal 65(3) p. 252-68, 2018.

[3] J. J. Exline, L. Everett, P. Worthington, Jr., P. Hill MEM. "Forgiveness and Justice: A Research Agenda for Social and Personality Psychology." Personal Soc Psychol Rev. Vol. 7, No. 4, pp. 337-48. 2003

[4] S. Julich \& T . Thorburn, "Sexual Violence and Substantive Equality: Can Restorative Justice Deliver?" Journal of Human Rights and Social Work Vol. 2, No. 1-2, p. 34-44, 2017

[5] K. Daly, "What is Restorative Justice? Fresh Answers to a Vexed Question," An International Journal of Evidence-Based Research, Policy and Practice, Vol. 11, No. 1, p. 9-29, 2016. See also M. Wenzel, "Retributive and Restorative Justice," Law and Human Behavior, Vol. 32, No. 5, p. 375, 2008

[6] J. Latimer, C. Dowden \& D. Muise, "The Effectiveness of Restorative Justice Practices: Meta-Analysis," The Prison Journal Vol. 85, No. 2, p. 127-44,2005

[7] M. K. Dhami, Apology in Victim-Offender Mediation Contemporary Justice Review, Vol. 19, No. 1, p. 31-42, 2016. See also M P Koss, K J Bachar, C Q Hopkins, "Restorative Justice for Sexual Violence," Sexually Coercive Behavior: Understanding and Management, Vol. 989 p. 384-396, 2003

[8] W. Twinning, "A Post-Westphalian Conception of Law," Law \& Society Review, Vol. 37 p. 199-258, 2003 